\title{
PEMBATASAN HAK ATAS INFORMASI ELEKTRONIK DALAM YURISDIKSI CYBERSPACE
}

\author{
Muhammad Effendi \\ Fakultas Hukum Universitas Gunung Rinjani \\ E-mail : fakhukum@gmail.com | Phone : +6281997958400 \\ Tulisan Diterima : 10-10-2019 | Direvisi : 18-10-2019 | Disetujui Diterbitkan : 4-11-2019
}

\begin{abstract}
Writing this thesis aims to find out the form of legal protection and restrictions on the right to information that can be done in cyberspace. Because of the rapid advances in technology, there are also more problems that arise from this virtual world, this is the background of this thesis writing because it is very important to know what can and should not be done according to laws governing the world this virtual. Some countries, including Indonesia, restrict the right to electronic information, although this kind of regulation, both formally and materially, is contrary to the rights of individuals to privacy and information, but there are other people's rights that also need to be protected and state security that must be protected. The birth of law number 11 of 2008 which was revised to law number 19 of 2016 is clear evidence of the limitation of the right to information in Indonesia, because Indonesia upholds human rights but with this law Indonesia also aims to maintain security or country stability. The conclusion reached is: that the state protects the right to information and the use of technology but is also obliged to protect the public interest from all kinds of disturbances arising from misuse of information, especially through electronic media that disturb public order, or so-called jurisdiction.
\end{abstract}

\section{Keywords; information restrictions, cyberspace}

\begin{abstract}
ABSTRAK
Penulisan skripsi ini bertujuan untuk mengetahui bentuk perlindungan hukum dan pembatasan hak atas informasi yang dapat di lakukan dalam dunia maya. Karena semakin pesatnya kemajuan tekhonolgi maka semakin banyak juga masalah yang muncul dari dunia maya ini, hal inilah yang menjadi latar belakang penulisan skripsi ini karena sangat penting untuk mengetahui hal apa saja yang boleh di lakukan dan tidak di lakukan menurut undang-undang yangh mengatur tentang dunia maya ini. Beberapa negara termasuk Indonesia melakukan pembatasan hak atas informasi elektronik, walaupun peraturan semacam ini, baik secara formal maupun secara materil memang bertentangan dengan hakhak individu atas privasi dan informasi akan tetapi ada hak orang lain yang juga perlu dilindungi serta keamanan negara yang harus dijaga. Lahirnya Undang-Undang Nomor 11 Tahun 2008 yang direvisi menjadi Undang-Undang Nomor 19 Tahun 2016 merupakan bukti nyata akan adanya pembatasan hak atas informasi di Indonesia, karena Indonesia menjunjung tinggi hak asasi manusia tetapi dengan Undang-Undang ini Indonesia juga bertujuan untuk menjaga keamanan atau stabilitas negara. Kesimpulan yang didapatkan adalah: bahwa negara melindungi hak atas informasi dan pemamfaatan tekhnologi tetapi juga wajib melindungi kepentingan umum dari segala jenis gangguan yang timbul akibat penyalahgunaan informasi khususnya melalui media elektronik yang mengganggu ketertiban umum, atau yang disebut yurisdiksi.
\end{abstract}

Kata kunci : pembatasan informasi, dunia maya. 


\section{Pendahuluan}

Teknologi adalah suatu hal yang sangat penting dalam proses kehidupan manusia. Hal ini tidak bisa di sangkal, kehadiran internet pada zaman sekarang ini, dimana internet ini menawarkan hal hal yang serba mudah dan serba cepat. Hampir semua kebutuhan kita tinggal kita pesan dan terima di rumah tanpa harus capek mencari kebutuhan kita itu. Hal ini bisa kita dapatkan karena internet sebab sekarang banyak sekali pelaku usaha yang menyandarkan proses pemasaran dalam usahanya melalui media internet, sehingga sekarang banyak kita lihat perdagangan Daring/online.

Indonesia menjadi salah satu negara di dunia yang pengguna internetnya tinggi. Berdasarkan survei yang dilakukan Hootsuite sebuah perusahaan platform media sosial di Kanada mencatat pengguna internet di Indonesia pada Januari 2019 mencapai 150 juta pengguna, jumlah tersebut meningkat dari tahun 2018 yang mencapai 143 juta pengguna ${ }^{1}$.

Perkembangan yang pesat ini tidak terlepas dari peran serta pemerintah yang proaktif dalam membantu perkembangan internet ini, pemerintah juga sangat memperhatikan akan keamanan, ketentraman dan kesejahteraan masyarakatnya.

Informasi yang berbasis internet memiliki prinsip Free Flow of Information', yaitu penyebaran dari informasi tersebut tidak dapat dihambat, namun tidak berarti seluruh informasi yang berbasis internet dapat diakses oleh siapapun tanpa batasan apapun. Setiap pemilik informasi dapat menentukan sendiri perlindungan privasinya terhadap informasi yang dimiliki oleh yang bersangkutan di dalam media internet.

Informasi yang berbasis internet merupakan informasi elektronik yang menjadi

\footnotetext{
${ }^{1}$ BOC Indonesia. 2019. "Statistik Pengguna Digital dan Internet Indonesia 2019". Diakses dari https://www. boc. web. id/statistik-pengguna-digital-dan-internet-indonesia-2019/

2 Mieke Komar Kantaatmadja, et. al. , Cyberlaw: Suatu Pengantar, ELIPS, 2002, hlm. 119.

Tulisan Sinta Dewi berjudul "Perlindungan terhadap Hak-hak Pribadi (Privacy Rights) dalam Transaksi melalui Elektronik" dikutip dari Abu Bakar Munir, Cyber Law: Policies and Challenges, Butterworths Asia, 1999, hlm. 106
}

nukleus atau bahkan nuklei (inti yang sangat esensial) dari Teknologi Informasi. ${ }^{3}$ Informasi elektronik adalah sekumpulan informasi yang di peroleh dari media elektronik yang telah diolah dan disampaikan kembali kepada masyarakat seperti dokumen elektronik, photo elektronik, informasi dari media elektronik dan lain-lain.

Berdasarkan hak asasi manusia sebagai mahluk ciptaan Tuhan yang Maha Esa manusia memiliki hak yang sama dalam kehidupan nya tanpa ada pembedaan dalam segala hal. oleh karena itu sangat penting bagi negara untuk melindungi hak asasi manusia tersebut. Pada ranah internasional melalui PBB, dunia juga memberikan perlindungan dan jaminan atas hak hak asasi tersebut,termasuk di dalam nya hak atas informasi dan memanfaatkan kemajuan Teknologi.

Perkembangan internet yang sangat pesat ini, dengan berbagai kemudahan yang ditawarkan dalam dunia maya/cyberface. Kondisi yang seperti ini juga berdampak negatif karena ada, oknum-oknum yang memanfaatkan dunia cyber ini untuk kepentingan pribadi semata tanpa memikirkan kepentingan orang lain dan nilai-nilai moral misalnya sering kita dengar istilah hacker atau para pembobol privasi Bank dimana kejahatan ini tidak dilakukan secara manual semuanya dilakukan dari jarak jauh dan dengan bantuan internet para oknum tinggal memindahkan angka-angka ke rekeningnya dan banyak lagi konten yang melanggar nilai etika, moral dan susila, sepeti pornografi serta perbuatan-perbuatan yang tidak pantas di perlihatkan secara umum.

Melihat masalah ini sangat penting untuk mengatur secara tegas dan jelas tentang perbuatan yang boleh dan tidak boleh di lakukan dalam cyberface ini. Peraturan semacam ini, baik secara formal maupun secara materil memang bertentangan dengan hak-hak individu atas privasi dan informasi. Akan tetapi, ada hak orang lain yang juga perlu dilindungi serta keamanan negara yang harus dijaga. Melihat realita yang ada seperti yang dijelaskan

\footnotetext{
${ }^{3}$ Ahmad M. Ramli, Pager Gunung, dan Indra Apriyadi, Menuju Kepastian Hukum di Bidang: Informasi dan Transaksi Elektronik, Departemen Komunikasi dan Informatika RI, Jakarta, 2005, hlm. 35
} 
di atas penulis tertarik untuk menggambarkan dan menjelaskan secara sistematis lingkup yurisdiksi tersebut dalam penelitian yang berjudul "Pembatasan Hak atas Informasi Elektronik dalam Yurisdiksi Cyberspace". Berdasarkan uraian latar belakang diatas, maka untuk memperoleh jawaban yang akan menjadi isi skripsi ini diajukan rumusan masalah sebagai berikut : Bagaimana bentuk pembatasan hak atas informasi yang dapat dilakukan oleh pemerintahan dalam dunia maya (Cyberspace). Adapun tujuan dilakukannya penelitian ini adalah untuk menggambarkan dan berbagai bentuk pembatasan hak warga negara atas informasi yang dapat dilakukan oleh negara demi terjaganya stabilitas negara dalam dunia maya (cyberspace). Ada dua manfaat yang sangat kami harapkan dalam penelitian ini yaitu Manfaat Teoritis dari Penelitian ini adalah agar seluruh informasi dan analisis yang dibuat di dalam penelitian ini akan dapat berguna bagi siapapun yang membacanya untuk dapat mengetahui batasan dan perlindungan atas Hak atas Informasi dalam dunia maya (cyberspace). Penulis ingin memahami dan mendalami tentang pembatasan hak dalam informasi dan apa saja yang membatasinya.

Metode Penelitian yang digunakan dalam penyusunan skripsi ini adalah Deskriptif Analitis, yaitu suatu penelitian yang dimaksudkan untuk memberikan data yang seteliti mungkin tentang manusia, keadaan, atau gejalagejala lainnya dan dilengkapi dengan analisa sebagai suatu penelitian hukum normative. Penulis menggunakan metode pendekatan Yuridis Normatif yang mencakup penelitian terhadap asas-asas hukum, sistematika hukum, taraf singkronisasi hukum, sejarah hukum, dan perbandingan hukum terhadap beberapa peraturan perundang-undangan yaitu UndangUndang Nomor 36 Tahun 1999 tentang Telekomunikasi, Undang-Undang Nomor 39 Tahun 1999 tentang Hak Asasi Manusia, Undang-Undang Nomor 25 Tahun 2009 tentang Pelayanan Publik, Undang-Undang Nomor 19 Tahun 2016 tentang Informasi dan Transaksi Elektronik, UUD 1945 pasal 28J, 28F, 28C ayat 1 dan Undang-Undang DUHAM. Dalam skripsi ini kami tidak memakai data sebab dalam penelitian ini sumber yang kami pakai hanya dari Undang-Undang, artikel-artikel hukum, dokumen-dokumen hukum yang bisa menunjang penelitian ini, kami tidak mencari dan memperoleh data dari lapangan.

\section{STUDI PUSTAKA DAN ANALISIS}

\section{A. Hak atas informasi sebagai hak individu}

Suatu informasi berasal dari suatu data (yang mencakup semua fakta yang direpresentasikan sebagai input baik dalam bentuk untaian kata (teks), angka (numerik), gambar pencitraan (images), suara, ataupun gerak), yang telah diolah sebaik mungkin agar baik bentuk dan nilai yang dihasilkan lebih baik dari sebelumnya.

Informasi memiliki peran dan fungsi yang sangat penting bagi manusia, karena bisa dikatakan informasi adalah anak tangga pertama dalam melakukan sesuatu, memutuskan suatu hal, bahkan informasi ini sangat berperan dalam pengambilan keputusan. Karakteristik suatu informasi yang baik akan ditentukan oleh kriteria-kriteria antara lain sebagai berikut: ${ }^{4}$

a. pertinence, yaitu informasi tersebut harus relevan dan dapat memberikan nilai tambah;

b. timeliness, yaitu informasi tersebut harus tersedia pada saat yang dibutuhkan;

c. accuracy, yaitu informasi tersebut harus akurat sesuai dengan konteks dan intensitas tujuan penggunaannya;

d. reduced uncertainty, yaitu informasi tersebut harus mendekati kepastian yang absolut;

e. element of surprise, yaitu informasi tersebut harus merupakan sesuatu yang aktual.

Dalam perkembangan teknologi ini peran pemerintah sangat penting karena dalam fenomena ini hanya pemerintah yang berhak dan berwenang untuk mengatur keseimbangan antara hak dan kewajiban baik terhadap pribadi, maupun terhadap manusia lainnya. Hal ini

\footnotetext{
${ }^{4}$ Ibid. , hlm. 31-32 Sebagaimana dinyatakan oleh David Kroenke
} 
bertujuan semata-mata demi ketentraman, keamanan, dan stabilitas negara.

Undang-Undang Dasar Negara Republik Indonesia Tahun 1945 menjamin Hak asasi manusia termasuk hak atas Informasi, dalam undang-undang ini pada pasal 28 terdiri dari 10 bagian yang semuanya mengatur segala bentuk kebebasan masyarakat dalam menjalankan kehidupan nya baik secara pribadi,kelompok, berbangsa dan bernegara. pasal 28 ini mulai dari pasal 28 A pasal 28J. Dalam pasal 28 ini, pasal 28J adalah yang paling beda dari semua bagian yang mengatur tentang hak asasi manusia ini.

Pasal 28 C (1)UUD 1945

Setiap orang berhak mengembangkan diri melalui pemenuhan kebutuhan dasarnya, berhak mendapat pendidikan dan memperoleh manfaat dari ilmu pengetahuan dan teknologi, seni dan budaya, demi meningkatkan kualitas hidupnya dan demi kesejahteraan umat manusia.

\section{Pasal 28F UUD 1945}

Setiap orang berhak untuk berkomunikasi dan memperoleh informasi untuk mengembangkan pribadi dan lingkungan sosialnya, serta berhak untuk mencari, memperoleh, memiliki, menyimpan, mengolah, dan menyampaikan informasi dengan menggunakan segala jenis saluran yang tersedia.

Pasal 28 J UUD 1945.

Ayat 1 . Setiap orang wajib menghormati hak asasi orang lain dalam tertib kehidupan bermasyarakat, berbangsa dan bernegara.

Ayat 2. Dalam menjalankan hak dan kebebasanya, setiap orang wajib tunduk kepada pembatasanya yang ditetapkan dengan undang-undang dengan dimaksud semata-mata untuk menjamin pengakuan serta penghormatan atas hak dan kebebasan orang lain dan untuk memenuhi tuntutan yang adil sesuai dengan pertimbangan moral, nilai-nilai agama, keamanan dan ketertiban umum dalam suatu masyarakat demokratis.
Dalam Undang-Undang Negara Republik Indonesia Nomor 39 Tahun 1999 tentang Hak Asasi Manusia juga mengatur mengenai Hak atas Informasi, yaitu :

Pasal 13

Setiap orang berhak untuk mengembangkan dan memperoleh manfaat dari ilmu pengetahuan dan teknologi, seni, dan budaya sesuai dengan martabat manusia demi kesejahteraan pribadinya, bangsa, dan umat manusia.

Pasal 14

Ayat 1: Setiap orang berhak untuk berkomunikasi dan memperoleh informasi yang diperlukan untuk mengembangkan pribadi dan lingkungan sosialnya.

Ayat 2: Setiap orang berhak untuk mencari, memperoleh, memiliki, menyimpan, mengolah, dan menyampaikan informasi dengan menggunakan segala jenis sarana yang tersedia. $^{5}$

Peraturan-peraturan perundang-undangan tersebut menjelaskan bahwa kebebasan memperoleh informasi telah secara sah telah dijamin oleh negara akan tetapi untuk menghindari konflik dan kekaucauan dalam masyarakat harus kita ingat bahwa kebebasan dalam menjalankan hak asasi manusia kita harus tetap menghormati hak asasi orang lain. Jadi dari bunyi Undang-Undang diatas kami mengambil kesimpulan bahwa hak asasi yang kita anut bukan kebebasan tanpa batas / kebebasan mutlak, hal ini dapat kami simpulkan dari pasal 28J di atas.

Seiring dengan semakin pesat nya kemajuan internet ini dan semakin banyak nya masyarakat yang memanfaat kan internet, menghadirkan begitu banyak hasil-hasil karya masyarakat melalui internet ini, kehadiran karya-karya masyarakat yang berbasis online baik dalam bidang ekonomi, seni, budaya, pendidikan, bahkan sampai karya-karya dalam bidang kuliner pun terpapar dengan lengkap

\footnotetext{
${ }^{5}$ Undang-Undang R. I. Nomor 39 Tahun 1999 tentang Hak Asasi Manusia, Pasal 13 dan 14. HIm. 7-8
} 
dalam internet ini, berbagai keuntungan bagi masyarakat antaranya: ${ }^{6}$

a. audience control, di mana masyarakat dapat leluasa memilih berita yang ingin mereka peroleh;

b. nonlinearity, memungkinkan setiap berita dapat berdiri sendiri sehingga masyarakat tidak harus membaca secara berurutan untuk memahaminya;

c. storage and retrieval, berita dapat disimpan dan bisa diakses kembali secara mudah oleh masyarakat;

d. unlimited space, berita jauh lebih lengkap dibandingkan dengan media lainnya karena tidak terbatasnya ruang yang tersedia;

e. immediacy, berita dapat mampu segera disampaikan secara langsung kepada masyarakat;

f. multimedia capability, berita dapat disampaikan berupa teks, suara, gambar, video, dan komponen lainnya; dan

g. interactivity, terbukanya kemungkinan partisipasi masyarakat dalam penyajian setiap berita.

Dalam dunia internasional yang tergabung dalam PBB menyepakati untuk selalu menjaga dan menjunjung tinggi hak asasi manusia. kehadiran undang-undang DUHAM adalah bukti nyata tentang pengakuan dan penghormatan atas hak asasi manusia tersebut. Undangundang DUHAM ini lahir dari kesepakatan beberapa negara yang tergabung dalam PBB pada tanggal 10 november 1948 yang disepakati oleh majlis umum PBB yang menyatakan :

\section{Pasal 12}

Tidak seorangpun boleh diganggu urusan pribadinya, keluarganya, rumah tangganya atau hubungan surat-menyuratnya, dengan sewenangwenang, juga tidak diperkenankan melakukan pelanggaran atas kehormatan dan nama baiknya. Setiap orang berhak mendapat perlindungan hukum terhadap gangguangangguan atau pelanggaran seperti itu.
Kovenan Internasional tentang Hak Sipil dan Politik (ICCPR) juga mengatur mengenai perlindungan hak atas informasi dan korespondensi sebagai hak individu sebagaimana yang dimuat dalam Pasal 17 dan Pasal 19 berikut ini :

\section{Article 17}

1. No one shall be subjected to arbitrary or unlawful interference with his privacy, family, home or correspondence, nor to unlawful attacks on his honour and reputation. 7

2. Everyone has the right to the protection of the law against such interference or attacks. ${ }^{8}$

(Yang artinya)

1) Tidak seorang pun akan mengalami gangguan sewenang-wenang atau melanggar hukum dengan privasi, keluarga, atau korespondensi, atau serangan tidak sah terhadap kehormatan dan reputasinya. .

2) Setiap orang berhak atas perlindungan hukum terhadap gangguan atau serangan semacam itu.

Article 19

1. Everyone shall have the right to hold opinions without interference.

2. Everyone shall have the right to freedom of expression; this right shall include freedom to seek, receive and impart information and ideas of all kinds, regardless of frontiers, either orally, in writing or in print, in the form of art, or through any other media of his choice.

3. The exercise of the rights provided for in paragraph 2 of this article carries with it special duties and responsibilities. It may therefore be subject to certain restrictions, but

\footnotetext{
${ }^{7}$ Ayat 1 Article 17 of the Universal Declaration of Human Rights. http://www. claiminghumanrights. org/privacy_definition. html

${ }^{8}$ Ayat 2 Article 17 of the Universal Declaration of Human Rights. http://www. claiminghumanrights. org/privacy_definition. html
} 
these shall only be such as are provided by law and are necessary:

(a) For respect of the rights or reputations of others;

(b) For the protection of national security or of public order (ordre public), or of public health or morals. ${ }^{9}$

(yang artinya)

1. Setiap orang berhak untuk memiliki pendapat tanpa gangguan.

2. Setiap orang berhak atas kebebasan berekspresi; hak ini harus mencakup kebebasan untuk mencari, menerima, dan memberikan informasi dan ide-ide dari segala jenis, tanpa memandang batas, baik secara lisan, tertulis atau cetak, dalam bentuk seni, atau melalui media lain yang dipilihnya.

3. Pelaksanaan hak-hak yang diatur dalam ayat 2 pasal ini disertai dengan tugas dan tanggung jawab khusus. Karena itu mungkin tunduk pada batasan tertentu, tetapi ini hanya akan seperti yang disediakan oleh hukum dan diperlukan :

a. Untuk menghormati hak atau reputasi orang lain;

b. Untuk perlindungan keamanan nasional atau ketertiban umum (ordre public), atau kesehatan masyarakat atau moral. Indonesia sebagai masyarakat internasional sangat menghormati dan menjunjung tinggi akan hak asasi manusia, hal tersebut dapat kita lihat dari adanya UndangUndang Negara Republik IndonesiaNomor39 Tahun 1999 Pasal 13 Dan Pasal14 Dan dimasukkan nya Pasal28 Pada batang tubuh Undang-Undang Dasar 1945.

\section{B. Kewenangan dan Kewajiban Negara dalam Yuridiksi Cyberspace}

Yurisdiksi adalah kekuasaan atau kompetensi hukum negara terhadap orang, benda, dan/atau peristiwa hukum. Secara sederhana yurisdiksi ini bisa diartikan yaitu hak dan wewenang sebuah negara dalam menentukan dan menjalankan hukum itu sendiri sesuai dengan kebutuhan masyarakat dan negaranya.

a. Prinsip-prinsip Yurisdiksi

Kedaulatan suatu negara termasuk di antaranya memiliki kekuasaan dan kewenangan sebagai berikut: ${ }^{10}$

1. kekuasaan menjalankan kewenangan atas segala hal yang berada di dalam wilayahnya; kekuasaan yang dimiliki oleh pemerintahan dari suatu negara dalam fungsi publik di wilayah teritorialnya disebut dengan yurisdiksi, yang dapat dibagi ke dalam:

a. yurisdiksi untuk menentukan peraturan perundanganundangan yang pada umumnya hanya berlaku di wilayah teritorial dari negara yang bersangkutan, dengan pengertian bahwa peraturan perundang-undangan dibuat oleh lembaga legislatif dari negara yang bersangkutan dengan kekuasaan dan kewenangan yang dimilikinya atas segala sesuatu di dalam wilayahnya, warga negaranya, baik warga negaranya yang tinggal di wila wilayahnya maupun di negara lain, ataupun warga negara asing yang tinggal di wilayah nya/ menetap di wilayah nya.
${ }^{9}$ Article 19 of the Universal Declaration of HumanRights. http://www. claiminghumanrights. org/privacy_definition. html

\footnotetext{
${ }^{10}$ Casesse, Antonio, International Law (Second Edition), Oxford University Press, Oxford, 2005, hlm. 49
} 
b. yurisdiksi untuk menerapkan hukum. Kekuasaan ini pada dasarnya merupakan kemampuan untuk melaksanakan suatu hukum baik peraturan perundangundangan maupun putusan pengadilan untuk setiap peristiwa dan/atau subjek hukum yang berada di dalam wilayah teritorial negara yang bersangkutan, dan tidak dapat dipaksakan oleh negara yang bersangkutan di luar wilayah teritorialnya, kecuali dengan adanya kemampuan yang diberikan kepada negara yang bersangkutan berdasarkan perjanjian internasional dan/atau kebiasaan internasional; dan

c. yurisdiksi untuk menjalankan proses peradilan;

Hukum Internasional mengenai 6 (enam) prinsip utama bagi dapat dilaksanakannya yurisdiksi ini oleh suatu negara, yaitu:

1) Teritorial Subjektif/Subjective Prinsip ini adalah prinsip yang dijalankan oleh seluruh negara di dunia, di mana suatu negara memiliki yurisdiksi atas segala peristiwa dan/atau individu yang berada di dalam wilayah teritorialnya.

2) Teritorial Objektif/Objective TPrinsip ini dapat dijalankan apabila suatu peristiwa terjadi di luar wilayah teritorial negara yang bersangkutan tetapi mempengaruhi negara yang bersangkutan secara langsung, di mana negara yang bersangkutan menjadi korban dari peristiwa tersebut, sering disebut sebagai yurisdiksi efektif, dan cukup memiliki relevansi yang tinggi di dalam penyelesaian permasalahan yang terjadi di cyberspace.

3) Nasionalitas aktif/Nationality
Prinsip ini adalahpengakuan yurisdiksi negara berdasarkan kewarganegaraan dari subjek hokum yang bersangkutan,pada umum nya di gunakan oleh negara yang menggunakan system hukum Eropa continental. Prinsip nasionalitas aktif dapat di aplikasikan atas individu di dalam cyberface dengan adanya kontak minimum dan pertimbangan keadilan substantial.

4) Nasionalitas Pasif/Passive Nationality Prinsip ini adalah pengakuan yurisdiksi negara berdasarkan kewarganegaraan korban. Prinsip ini biasanya digunakan apabila dapat diaplikasikan bersama dengan prinsip nasionalitas aktif. Prinsip ini jarang digunakan karena dianggap tidak menghargai hukum negara asing dan karena korban bukanlah orang yang akan diadili, untuk menjalankan suatu proses peradilan,maka yang diadili adalah pelaku dan bukan korban;

5) Protektif/Protective Principle Prinsip ini menekankan bahwa suatu negara dapat memiliki yurisdiksi atas peristiwa dan/atau individu yang mengancam keamanan dan integritas negara yang bersangkutan, tanpa melihat kewarganegaraan maupun di mana peristiwa dan/atau individu tersebut berada. Prinsip ini sangat jarang digunakan dengan pertimbangan pengaplikasian prinsip ini dapat menyinggung kedaulatan dari negara lainnya;

6) Universality

Prinsip yurisdiksi universal memberikan kemampuan bagi negara manapun untuk menangkap dan/atau mengadili suatu peristiwa dan/atau individu yang melanggar prinsipprinsip hukum umum (pembajakan, kejahatan hak asasi manusia, pembantaian massal, dan perbudakan).

Secara sederhana Yurisdiksi sebagai hak dan wewenang Negara dalam menentukan dan 
menjalankan hukum sesuai dengan kondisi negara pada saat itu atau sesuai dengan kebutuhan Negara. Secara sederhana yurisdiksi di bagi menjadi 3 (tiga) yaitu :

1) Yurisdiksi legislatif merupakan kewenangan pembuatan hukum substantive (oleh karena itu, disebut yurisdiksi legislatif, atau dapat juga disebut "yurisdiksi formulatif").

2) Yurisdiksi yudisial merupakan kewenangan mengadili atau menerapkan hukum (oleh karena itu disebut yurisdiksi yudisial atau aplikatif ).

3) Yurisdiksi eksekutif merupakan kewenangan

melaksanakan/memaksakan

kepatuhan hukum yang dibuatnya (oleh karena itu, disebut yurisdiksi eksekutif. sumber " Bambang Sutioso dalam bukunya manajemen etika dan hukum teknologi informasi" 2015.

\section{Dasar Negara Membatasi Hak Atas Informasi}

Pembatasan dalam dunia cyber ini sangat perlu di lakukan karena bisa di katakana bahwa hamper semua lapisan masyarakat baik dari anak-anak sampai orang tua sudah memanfatkan internet ini ,banyak nya kontenkonten yang tidak sesuwai dengan norma kesopanan dan kesusilaan membuat negara atau pemerintah harus membatasi kebebasan dalam dunia internet ini,oleh sebab itulah negara membuat beberapa undang-undang yang membatasi dalam pemamfatan internet ini diantaranya:

1. Undang-Undang nomor 36 tahun 1999 tentang telekomunikasi pasal 21. yang bunyinya"penyelenggara telekomunikasi di larang melakukan kegiatan telekomunikasi yang bertentangan dengan kepentingan umum, kesusilaan,keamanan, atau ketertiban umum".

2. Undang-Undang nomor 25 tahun tahun 2009 tentang tentang pelayanan publik pasal 5 yang bunyinya " Dalam menyelenggarakan pelayanan publik tidak diperbolehkan untuk membocorkan informasi atau dokumen yang wajib di rahasiakan sesuai dengan peraturan perundangundangan".

3. Undang-Undang nomor 44 tahun 2008 tentang pornografi pasal 4 yang bunyinya "Setiap orang di larang memproduksi, membuat, memperbanyak, menggandakan, menyebarluaskan, menyiarkan, mengimport, mengekspor, menawarkan, memperjual belikan, menyewakan, atau menyediakan pornografi yang secara eksplisit memuat : persenggamaan, termasuk persenggamaan yang menyimpang.

a. Kekerasan seksual

b. Masturbasi/onani

c. Ketelanjangan atau tampilan yang mengesankan ketelanjangan.

d. Alat kelamin, atau

e. Pornografi anak

4. Surat Edaran Atas Nama Menteri Komunikasi dan Informasi NO. 1598/SE/DJPT. KOMINFO/7/2010Tentang kepatuhan terhadap peraturan perundangundangan yang terkait dengan pornografi, melakukan pembatasan hak atas informasi bagi pengguna internet dengan menginisiasikan keyword filtering yang di lakukan oleh internet service provider(isp) atau penyedia layanan internet, terkait dengan konten informasi yang di sampaikan.

5. Undang-undang nomor 11 tahun 2008 tentang informasi dan transaksi elektronik yang di revisi kembali menjadi undang-undang nomor19 tahun 2016 yang dalam undangundang ini di atur dengan jelas dan tegas tentang apa yang boleh dan tidak boleh di lakukan dalam dunia cyber.

Mengingat sifat internet yang tanpa batas undang -undang ITE ini menganut prinsip territorial objektif hal ini dapat di lihat dari pasal 
2 undang-undang ini yang bunyinya: "UndangUndang ini berlaku untuk setiap orang yang melakukan perbuatan hukum sebagaimana diatur dalam Undang-Undang ini, baik yang berada di wilayah Hukum Indonesia maupun diluar wilayah hukum Indonesia, yang memiliki akibat hukum di wilayah hukum Indonesia dan merugikan kepentingan Indonesia. "

Dalam Undang-Undang ITE ini segala bentuk aspek perbuatan yang dilarang dalam dunia cyberface diatur dalam Bab VII UndangUndang ini yang berisi 10 Pasal yaitu mulai dari pasal 27 sampai pasal 37 Undang-Undang ini yang isinya segala bentuk perbuatan yang tidak boleh di lakukan dalam dunia maya ini.

Didalam undang-undang ITE ini juga di atur dengan jelas peran serta pemerintah dalam penyelenggaran internet ini, yang harus di lakukan secara optimal agar tercipta setabilitas negara,hal ini dapat kita lihat dalam pasal 40 undang-undang ITE yang bunyinya :

1. Pemerintah memfasilitasi pemanfaatan Teknologi Informasi dan Transaksi Elektronik sesuai dengan ketentuan peraturan perundangundangan.

2. Pemerintah melindungi kepentingan umum dari segala jenis gangguan sebagai akibat penyalahgunaan Informasi Elektronik dan Transaksi Elektronik yang mengganggu ketertiban umum, sesuai dengan ketentuan peraturan perundangan dengan.

(2a) Pemerintah wajib melakukan pencegahan penyebarluasan dan penggunaan Informasi Elektronik dan/ atau Dokumen Elektronik yang memiliki muatan yang dilarang sesuai dengan ketentuan peraturan perundang-undangan.

(2b) Dalam melakukan pencegahan sebagaimana dimaksud pada ayat (2a), Pemerintah berwenang melakukan pemutusan akses dan/atau memerintahkan kepada Penyelenggara Sistem Elektronik untuk melakukan pemutusan akses terhadap Informasi Elektronik dan/ atau Dokumen Elektronik yang memiliki muatan yang melanggar hukum.

3. Pemerintah menetapkan instansi atau institusi yang memiliki. data elektronik strategis yang wajib dilindungi.

Undang-Undang ITE ini rezim hukum baru Dalam Undang-Undang Negara Republik Indonesia, akan tetapi walaupun hukum yang baru lahir UndangUndang ITE ini sangat disegani oleh masyarakat karena sanksi yang ada dalam undang-undang ini sangat berat dan tidak sesuai dengan perbuatan yang di lakukan mulai dari sanksi penjara dan denda yang sampai ratusan juta, dalam Undang-Undang ini walaupun kesalahan yang dilakukan hanya dengan memainkan jari jemari saja, sanksi yang di berikan dalam undang-undang ITE ini jauh lebih berat daripada sanksi yang ada dalam KUHP.

Contoh kasus yang pernah dijerat dengan undang-undang ITE.

1. Prita Mulyasari

Kasus Prita Mulyasari diawali dengan tersebarnya surat elektronik Prita yang berisi tentang keluhan pelayanan dari rumah sakit Omni Internasional. Kasus yang mencuat pada tahun 2009 ini merupakan salah satu kasus pertama yang menonjol yang berkaitan dengan UU ITE. Prita diganjar Pasal 27 ayat 3 UU ITE tentang distribusi informasi atau dokumen elektronik yang memuat kebencian atau pencemaran nama baik.

2. Ariel Noah

Kasus video syur Ariel dengan beberapa selebriti papan atas Indonesia pada tahun 2010 tentu tidak bisa dilupakan. Ariel Noah dijerat dengan UU ITE karena terbukti membuat dan menyebarkan video rekaman pornografi dan dia di hukum 3,5 tahun penjara dan di denda 250 juta rupiah.

3. Florence Sihombing (MAHASISWA S2 UGM) 
Karena membuat status Path yang berisi hinaan terhadap warga Yogyakarta, Floren Sihombing sempat ditahan 2 hari oleh Mapolda DI Yogyakarta. Dia di duga melanggar pasal 27 ayat 3 UU ITE. Ungkapan kekesalan nya di buat di akun situs pertemanannya yang isinya :

"Jogja miskin, tolol, miskin dan tak berbudaya. Teman-Teman Jakarta, Bandung, jangan mau tinggal di jogja." ungkapan ini inilah yang membuatnya kena Undang-Undang ITE.

4. Kasus BAIQ NURIL dari MATARAM. Kesalahan yang menyebabkan Baiq Nuril di hukum dengan UndangUndang ITE adalah karena tersebarnya rekaman percakapan antara dirinya dengan oknum kepala sekolah SMA 7 mataram berinisial ' $M$ ' yang berisi tentang pengalaman seksual nya dengan perempuan yang bukan istrinya. BAIQ NURIL membagikan/ mentransmisikan rekaman ini pada rekan kerjanya, kemudian rekan kerjanya tersebut menyebar luaskan rekaman tersebut. Alhasil oknum kepala sekolah yang mengetahui hal ini melaporkan Baiq Nuril ke polisi, Baiq Nuril pun di proses secara hukum dan pada tanggal 26 september 2017. Baiq Nuril di ponis penjara 6 bulan dan denda 500 juta rupiah. Vonis ini di jatuhkan karena di duga melanggar pasal 27 ITE ayat Jo pasal 45 ayat (1)

\section{PENUTUP}

\section{A. Kesimpulan}

Dari uraian singkat di atas kita dapat menarik kesimpulan bahwa negara melindungi hak dan kebebasan setiap warga negara dalam memanfaatkan informasi dan kemajuan tekhnologi akan tetapi hak dan kebebasan itu harus tunduk pada batasan- batasan yang telah di tetapkan oleh negara karena kita tidak menganut HAM yang bebas tanpa batas, hal ini dapat kita lihat dari undang-undang dasar 1945 pasal $28 \mathrm{j}$ yang dengan jelas membatasi segala bentuk kebebasan yang di atur dalam HAM.
Pembatasan ini di lakukan oleh negara semata-mata demi terciptanya setabilitas negara dan agar masyarakat selalu menjunjung tinggi nilai- nilai luhur bangsa Indonesia. Pembatasan ini sangat perlu di lakukan karena internet ini sudah menjadi kebutuhan masyarakat sekarang ini, mulai dari pendidikan sampai dunia kerja bisa dikatakan sudah mulai bersandar dalam dunia internet ini. Oleh sebab itu segala konten yang bermuatan negatif harus di saring agar tidak merusak pola fikir masyarakat,khusus nya generasi muda.

Lahirnya Undang-Undang Nomor 11 Tahun 2008 adalah bukti nyata bahwa pemerintah sangat memperhatikan hak setiap warga negara dan sangat memperhatikan setabilitas masyarakat,bangsa dan negara.

\section{B. SARAN}

1. Perkembangan kehidupan virtual (virtual reality) perlu diimbangi dengan pembuatan suatu norma sosial di dalam masyarakat pengguna internet (netizen) itu sendiri sehingga nilai-nilai kemanusiaan dapat tetap terjaga dalam komunikasi global. Pengaturan yang dibuat berdasarkan norma sosial ini disesuaikan dengan kebudayaan dari masing-masing netizen dan perlu diketahui batas hak dan kewajiban dari masing-masing netizen dalam menggunakan hak atas informasinya; dan

2. Penulis berharap kepada pemerintah untuk lebih memperketat pengawasan terhadap konten-konten yang bermuatan pornografi dan perjudian, karena sampai saat ini masih banyak kita lihat dalam dunia cyberface, konten yang bermuatan fornografi dan perjudian yang sangat mudah diakses oleh masyarakat, hal ini semata-mata demi kesejahteraan masyarakat dan untuk mengurangi pekat ( penyakit masyarakat ) yang disebabkan oleh konten-konten tersebut. 


\section{DAFTAR PUSTAKA}

\section{A. Buku-Buku}

Arief Dikdik dkk. M. Mansur dan Elisatris Gultom, Cyber Law: Aspek Hukum Teknologi Informasi, Refika Aditama Persada, Bandung, 2005

Henry H. Peritt, berjudul Jurisdiction in Cyberspace: The Role of Intermediaries

Makarim Edmon, kompilasi hukum telematika, Raja Grafindo, Jakarta, 2003

Munir Abu bakar. cyberlaw policies and challenges, butterworths asia, 1999

Ramli Ahmad M dkk. Menuju Kepastian Hukum di Bidang: Informasi dan Transaksi Elektronik, Departemen Komunikasi dan Informatika RI, Jakarta, 2005

\section{B. PERATURANPERUNDANG-UNDANGAN}

Indonesia, Undang-Undang Dasar RI 1945 pasal 28 tentang Hak Asasi Manusia

Indonesia, Undang-Undang RI Nomor 39 Thn 1999 Tentang Hak Asasi Manusia

Indonesia, Undang-Undang RI Nomor 19 Thn 2016 Tentang Informasi Dan Transaksi Elektronik.

Indonesia, Undang-Undang RI Nomor 5 Tahun 2005 Tentang Pelayanan Publik Undang

Indonesia, Undang-Undang RI Nomor 44 Tahun 2008 Tentang Pomografi UndangUndang RI Nomor 36 Tahun 1999 Tentang Telekomunikasi.

\section{Internet}

BOC Indonesia. 2019. "Statistik Pengguna Digital dan Internet Indonesia 2019". Diakses dari https://www. boc. web. id/statistik-pengguna-digital-dan internetindonesia-2019

http://rendapradana4646. blogspot. com/201 5/10/manfaat-teknologi telematika. $\mathrm{html} \% 3 \mathrm{Fm} \% 3 \mathrm{D} 1$ 